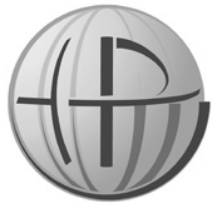

Horyzonty Polityki 2019, Vol. 10, No 33

\section{JaCEk Surzyn}

http://orcid.org/0000-0001-7959-243X Jesuit University Ignatianum in Krakow

Institute of Philosophy jacek.surzyn@ignatianum.edu.pl

DOI: 10.35765/HP.2019.1033.03

\title{
Tyrant and His Power According to John of Salisbury
}

Abstract

RESEARCH OBJECTIVE: The purpose of this article is to attempt to define tyranny in the concept of the medieval philosopher John of Salisbury.

THE RESEARCH PROBLEM AND METHODS: Salisbury is one of the most interesting political thinkers of the Middle Ages. His book entitled "Policraticus" became one of the most important political texts of the Middle Ages, which analyzes, among others, the problem of political authority, the separation of secular and spiritual powers, the problem of the relationship of the ruler with his subjects, as well as the issue of civil obedience and the transformation of legal power into unlawful power. The author tries to show the mechanisms leading to tyrannical power.

THE PROCESS OF ARGUMENTATION: The text analyzes all aspects of the tyrannical political power, comparing it to that of a legitimate prince. The tyrant is shown against the background of theological and political assumptions, also in the context of social justice and citizens' rights.

RESEARCH RESULTS: The tyrannical authority is, by its very nature, wrong and does not lead to social harmony and peace. The tyrant is an usurper and his power is immoral and unlawful. As an unjust ruler, the tyrant stands against the divine order and must take into account the inevitability of punishment. At the same time, this punishment for a tyrant falls within the moral and theological contexts, that is, it is a punishment which God sets. 
CONCLUSIONS, INNOVATIONS, AND RECOMMENDATIONS: Salisbury' thought seems to be valid because it is a part of the eternal problem of the dependence of political authority on morality, as well as the tendency to abuse political power over subjects.

\section{KeYwORDS:}

tyrant, political power, God, justice, goodness

\section{PROBLEM AND RESEARCH METHODS}

The main research problem of this paper is an attempt to answer the question, what are the basis of the tyrant's power and how is possible the collapse of the power given by God (that is, the power of prince) and its transformation into wrong one. The problem is analyzed using a comparative method, which is based on the analysis of the source text, that is Salisbury's "Policraticus." The problem is considered in the context of the relationship of two elements of each power, that is, the violence that each ruler possesses, and justice, which in turn seems to be the fundamental rule of social life. What connects violence and justice is a law that seems to be the final condition for legitimate (good) and illegitimate (bad) powers.

Leo Strauss at the beginning of his book On tyranny writes that modern political philosophy is not enough to understand the phenomenon of political tyranny, because in the context of our time it was not able to recognize the worst type of tyranny in history:

when we were brought face to face with tyranny-with a kind of tyranny that surpassed the boldest imagination of the most powerful thinkers of the past-our political science failed to recognize it (Strauss, 2000, p. 23)

The pessimistic picture sketched by an excellent researcher shows a some kind of "intellectual" helplessness in the face of tyranny, which as system of governing is always a denial of real, proper power.

The issue of tyranny has been extensively described in ancient Greece as a kind of defect and distortion. Plato in his fundamental political reflection understood tyranny in terms of the fall of social life as the most degenerate system of the government, which is nothing 
more then an apotheosis of the final collapse of the community. ${ }^{1}$ According to him, tyranny presentes the worst power emerging from the corruption of the democratic system, and at the same time he considered tyranny the furthest from the idea of the perfect state kallipolis. ${ }^{2}$ Aristotle had also a bad opinion about tyranny, except that he placed it as oppositon of royal power, and therefore as a bad alternative to the royal system. He also pointed out what conditions must be realize for tyranny to happen. At the same time, they both Plato and Aristotle indicate what must be met in order for a tyrant to be overthrown. ${ }^{3}$

The problem of tyranny was also taken up in the Middle Ages, and one of the most interesting theoreticians of political power, John of Salisbury conducted comprehensive considerations on this issue in his famous work entitled Policraticus (Nederman, 2015, pp. 258-259). In Salisbury's concept, the definition of the tyrant and his power is determinated primarily by the contradiction of his power with the divine order (Nederman, 2005, pp. 20-24). Salisbury clearly emphasizes that the tyrant does not has power from God - potestas a Deo, which, in general, means that in his action he is not able to meet any postulate related to the proper implementation of power. This lack of potestas a Deo is principal, as it means that the tyrant is outside any political or legal structure, and consequently his conduct has hallmarks of crime and sin. In other words, Salisbury assumes that the lack of Divine legitimacy of tyrant's authority means that one could go as far as killing him without being punished for sin or other kind of sanction (Nederman, 2015, pp. 265-266). In general, then, this concept justifies the overthrow of the tyrant's power by all possible means, assuming that all such action is good, because it restores the proper, that is, divine social (and political) order. All of this is based

1 The most important text in which Plato presents the origins of tyranny is Book VIII of his work "Republic."

2 The latest work a comprehensive discussion of this issue see: Arruzza, 2019; see also for exmaple: Cahn, 2002.

3 These issues have been widely discussed in the literature. The classic book, without which it is difficult to argue about the issues of state, power and politician in the ancient Greece is Meier, 1990. See also interesting selected books and articles: Jordović, 2011, pp. 26-64; Blackburn, 2006; Platon, 1997; Lorenz, 2006; Frank, 2005; Keyt, 2017, pp. 165-195. 
on the principle that the tyrant is an anti-legalist and thus he acts against the corpus justitie (Johannes Saresberiensis, 1855, p. 512), thus committing a public crime. Therefore, the punishment towards him is a legally grounded punishment.

John of Salisbury defines a tyrant in two ways. One definition refers to adulatio morality, the other is grounded in the law of usurpatio (Brucker \& Foulechat, 1987, p. 23). The first definition we could find in Book IV of Salisbury's work, the second definition is mainly in Book VIII. First of all, the tyrant's power is compared to the prince's legal power. Salisbury presents the prince as the ruler of the divine bestowal, as the representative of divine power: imago Deitatis (Johannes Saresberiensis, 1855, p. 778). The prince acts according to God's will, therefore he also represents the right - lex (Johannes Saresberiensis, 1855, pp. 780-781; see Kerner, 1977, pp. 149-152). Thus, the prince's authority meets all legal requirements and has full reverence. The prince has full dignity and his authority should be permanent and strong. On the contrary, the tyrannical authority is illegal, unworthy and should be unconditionally eliminated (Johannes Saresberiensis, 1855, pp. 778-779) ${ }^{4}$. There are also legal conditions for achieving this goal - plerumque occidentus. The one type of tyranny is its religious version, in which the tyrant is the head (caput) of a community of heretics and schismatics basing his power on spiritual and religious foundations. According to Salisbury, this type od tyranny is represented by all the authorities of the eastern satraps, which Pseudo-Plutarch described in detail in the work Institutio Traiano (Nederman, 2015, p. 260). The Satraps-tyrants use power solely for their own benefits, and for their legitimacy they resort to divine sanction. Their only driving force is the unbridled desire for power and profit, which means that they do not count with anyone or anything (Sasster, 2015, p. 241$)^{5}$.

4 An example of the difference between a prince and a tyrant: "Est ergo tiranni et principis haec differentia sola uel maxima quod hic legi obtemperat et eius arbitrio populum regit cuius se credit ministrum" (Johannes Saresberiensis, 1855, p. 513).

5 "Est ergo tyrannus, ut eum philosophi depinxerunt, qui uiolenta dominatione populum premit, sicut qui legibus regit princeps est. Porro lex donum Dei est, aequitatis forma, norma iustitiae, diuinae uoluntatis imago, salutis custodia, unio et consolidatio populorum, regula officiorum, exclusio et 
The second type of tyranny is his secular version, in which the power is taken over by pure violence and based on it. In this case, the tyrant does not has to appeal to any divine sanction, but he obtains and maintains it through usurpation - it means through arbitrary attribution it to himself (Johannes Saresberiensis, 1855, pp. 783-784). From the above considerations, which show a twofold type of tyranny, Salisbury assumes that the ultimate definition of tyrant's power is grounded in the fact that in a legal sense he abuses his authority, which in turn is based on hidden-secret foundations (Johannes Saresberiensis, 1855, p. 786).

John gives various examples from the period of the ancient Roman history, which are to show how tyranny comes to the power. The statement here is that the tyrant concentrates all his effort towards strengthening and maintaining his power, ignoring almost completely (unless it is directly related to its own goals) public good and happiness of his subjects. This implementation is sanctioned by the tyrant's special privileges (Johannes Saresberiensis, 1855, pp. 786-788). Particularly extensive scope of these privileges concerns tyranny based on religious grounds (Johannes Saresberiensis, 1855, pp. 791-792; see Nederman, 2015, pp. 266-267).

With all these in mind, John of Salisbury introduces the character of a public tyrant (see Nederman, 2015, pp. 268-269). A public tyrant appears when a legitimate prince abuses his power and thus transforms into a usurper. Of course, irrevocably question arises here, why such a situation is possible, since the position of a prince, unlike a tyrant, is sanctioned by God and refers to Divine law. In other words, there is the question: how is it possible for a legitimate and good prince to turn into an evil and illegitimate tyrant, since his power and himself are grounded in divine sanction (see Johannes Saresberiensis, 1855, pp. 793-796). In the Policracitus we could not directly find the answer to this question. It seems only that there is a suggestion that it is happening because of some moral weakness of the prince which inevitably leads him to sin. After all, this problem was not something new in Salisbury's time, for it seems to be one of the most important issues of political thinking in general. Already in

exterminatio uitiorum, uiolentiae et totius iniuriae poena" (Johannes Saresberiensis, 1855, p. 777). 
the times of ancient Greece, this issue was considered, and perhaps a premise that can be found in Salisbury's arguments is the problem of a tension between violence (bia) in one side and justice (dike) in another. In other words, the problem boils down here to the justification of the use of violence and the strong separation of it what is pure violence, or injustice, from it what is justice and therefore is good (see O'Daly, 2018, pp. 186-188). This problem is most clearly manifested in the order of social life, for one of the dispositions of the authorities is the possibility, or even the need to use violence, and Salisbury does not take away this from both the prince and the tyrant.

At the beginning it should be pointed out that justice and violence belong to different orders, although they come together in the exercise of power and governance. For Salisbury, the mode they connects with each other makes it possible to distinguish a prince from a tyrant. It what connects violence and justice is law, in means that law is a factor in which exercising power and using violence in governing is not bad or does not lead to sin. In other words, the use of violence by a ruler by law is justified (Sasster, 2015, pp. 242-243; O'Daly, 2018, pp. 185-186). Therefore, there is no contradiction between violence and justice, because the action applied refers to legal sanction, and the task of law is appropriate, that is, fairly outlining the possibility of using violence. In his concept, John of Salisbury would be inclined to accept such a solution, because on the one hand it allows for a clear separation of the righteous prince from an illegal tyrant, because illegal tyrant acts unjustly, i.e. he uses violence unlawfully (and this is caused by the lack of legitimacy his authority), on the other hand, this solution gives strong power in the form of the possibility of using violence to a legal prince, of course, provided that he acts in accordance with the law, i.e. uses violence in justified cases ( $\mathrm{O}^{\prime}$ Daly, 2018, pp. 188-189). ${ }^{6}$ Therefore, on the one hand, we have the prince's ability to act (Sasster, 2015, pp. 249-250), and on the other hand, perhaps a responce to the earlier question, why good prince can become

6 "Princeps tamen legis nexibus dicitur absolutus, non quia ei iniqua liceant, sed quia is esse debet qui, non timore poenae sed amore iustitiae aequitatem colat, rei publicae procuret utilitatem, et in omnibus aliorum commoda priuatae praeferat uoluntati" (Johannes Saresberiensis, 1855, p. 516). 
wrong tyrant. Generally speaking, such a situation can has a place when the prince's activity lacks compliance with the law, i.e. when he uses violence beyond the requirements of the law. ${ }^{7}$ Such a prince is transformed into a ruler who is unjust by virtue of his actions, but what is important, according to Salisbury, despite criticism and condemnation of the way he rules his power, however, one cannot take away a prince, who already became a tyrant, the attributes of his political authority, because in this case they are result from the fact that he obtained them as a legal ruler (Johannes Saresberiensis, 1855, p. 793).

There is no doubt that for John of Salisbury the law, and thus all legitimacy of any action which is compatible with its (i.e. just action) is the law given by God, so it has a divine sanction. Therefore, under this condition, this law is always and absolutely perfect, which means that violence and justice are in perfect harmony within it. In consequence, by applying such a law, there is no possibility of wrongdoing, and thus there is no dominance of violence over justice. A further consequence of the above presupposition is also the sanctioning of the power, which is right and justified only when it is fully implemented within the framework of God's law. This status characterizes the prince's authority and gives him complete freedom in making political decisions related to the exercise of the power. In this context, the evil which is arised from the tyrant's power is also revealed, even if his atricity is recognized to us. The tyrant obtained prerogatives of the power as a prince in a legal way, but he uses them unlawfully, i.e. in the domination of violence over justice. It destroys the social order defined by God's sanction (by Divine law) with all its consequences. So this is a critical and destructive situation for the social community-society, which is the cause why Salisbury uses the term of "public tyrant" as the example for an annihilation the authority of a legitimate prince by domination of unlimited violence (i.e. one whose wrong action directly affects what is "public" - res publica) (O'Daly, 2018, p. 189).

Searching for the reasons for this possibility (that is, the transformation of the prince into the tyrant) - because in the description so

7 This is the way to the worst type of tyranny. This problem is analyzed in: van Laarhoven, 1984, pp. 319-341. 
far, in principle, Salisbury tried only to explain when such a situation is placed, and not why is it possible - one should refer no longer to political and social considerations conducted in the Policraticus, but to the philosophical assumptions of the thought of John of Salisbury. He was a representative of $12^{\text {th }}$-century nominalism with skeptical tendencies. This skeptical tendency was manifested, inter alia, in the fact that Salisbury rather excluded the possibility of man's acquiring knowledge that would prove sufficient for full recognition of Divine law and thus its proper application. The only possibility of effective action appeals to faith and the act of God's grace. Nevertheless, man in the world (pro statu isto) remains a free being and it what influences his action-conduct is a some conglomerate of principles flowing directly from faith, and from it what he can some way know-recognize, and from the act of will, which ultimately is always free in its action. A lack of full harmony between these components can cause a fall and thus can contribute to the transformation of the prince into a tyrant. This is one way to explain why the prince can become the tyrant.

In connection with the issue, Salisbury also points to an extremely important distinction that actually determines the meaning of tyranny, namely, the tyrant's most important responsibility comes down to moral responsibility, and that means he is a responsibility to God. So everything that the tyrant wrong does, ultimately regards to God, and only God has the right to punish him, even if He does it with the help of the hands of people (see O'Daly, 2018, pp. 192-193). The tyrant is the opposite of a good, legitimate prince who is understood as imago Dei, and therefore the tyrant is an image of evil, which in religious language Salisbury describes in terms of "Lucifer's weaknesses." In the effect, to his reflections Salisbury introduces the theological dimension of the tyrant's responsibility, which in consequence causes his unjust, unlawful action to be judged primarily from the perspective of original sin and the fall of man, so it has a moral dimension, so as a result it brings God's, not human, punishment. This fundamental distinction must be remembered because it situates the assessment of the tyrant's actions in terms of theological order, not human order. Man, therefore, hasing the ability to act only in human order, generally has no right to punish an injustice of the tyrant, so from this perspective one can risk the think that in relation to human jurisdiction, the tyrant remains outside of it. Man, 
therefore, has no right to punish a tyrant, but this does not lead to the conclusion that the tyrant remains unpunished at all. It is just the contrary - there is God's responsibility to punish the tyrant and God can act in many ways. He can act alone, but He can also act through others, including people. Thus, the punishment that falls on the tyrant for unjust, sinful action can only be given by God, is determined in theological order and does not apply to life on earth. In justifying such a thought, Salisbury refers to the fact that for a tyrant, exercising power is already a punishment, because he is always associated with constant fear and uncertainty of maintaining power (Nederman, 2015, p. 273). Therefore, all his effort is directed not even to profit from his power, but to constantly care for its keeping, because it is constantly under threat. More important than, say, the earthly dimension of the tyrannical authority seems to be the theological dimension relating to eternity, for tyrant lives in a permanent catastrophic perspective of eternal damnation.

Another important problem is following: the tyrant's power contains a contradiction that is irremovable. On the one hand, the tyrant undoubtedly does evil, which must be condemned and must be punished (this punishment, however, is related to Divine will, because as I described before - the evil of tyranny refers to the moral sphere, which is reserved for God Himself), but his actions can carry out some divine plan, and then they could be understand in the general context of predestination. Salisbury gives the example of the famous Attila, who called himself a "God's whip":

From this we see that during the persecution by the Huns, Attila was questioned by the holy bishop of a certain city about who he was, to which he responded: "I am Attila, scourge of God"; the bishop venerated him (it is written) as a divine majesty. He said, "The minister of God is well honoured"; and also, "Blessed is he who comes in the name of God." The gates of the church were mournfully unbarred to admit the persecutor through whose hand martyrdom was attained. For he had not the audacity to exclude the scourge of God because he knew that His cherished son had been scourged and that there was no power to scourge him except from the Lord (Salisbury, 1990, p. 29).

So there is here a difficult issue related to submission to God's plan, even when it is implemented through an authority of the tyrant. However, the contradiction that appears here is only apparent, because it 
is the result of connecting of human order with Divine one. In other words, the tyrant acts in the human order and he can be effective only in it, at the same time fitting into a scheme of God's predestination. His actions cannot disturb the Divine order, although the evil, which he creates, results in the suffering of the others (his subjects) and it is a sin for which tyrant will answer before God. In an universal dimension, the tyrant's actions cause only a lack of harmony between violence and justice, i.e. there is no law but lawlessness (Nederman, 2015, pp. 276-277). And only in this sense the position of tyrant and tyranny can be properly understand. Therefore, John of Salisbury pointes out an important thesis on a depravity of power: bad power is a effect of lawlessness, i.e. using of violence without reference of justice. The tyrant uses his power in such an unjustified way. His attitude is fundamentally wrong, but these evil and sin are connected only with him as the decision-maker for his actions. But these activities understood as themselves are part of the whole of God's plan and in this sense they must fulfill God's will and perform some important function (of punishment, admonition, warning etc.), as in the given case of Atylla.

\section{REFERENCES}

Arruzza, C. (2019). A Wolf in the City: Tyranny and the Tyrant in Plato's Republic. Oxford: Oxford University Press.

Blackburn, S. (2006). Plato's „Republic”: A Biography. New York: Atlantic Monthly Press.

Brucker, Ch. \& Foulechat, D. (1987). Tyrans, princes et prêtres.(Jean de Salisbury, Policratique IV et VIII). Montrèal: Edition Ceres.

Cahn, S.M. (2002). Classics of Political and Moral Philosophy. Oxford: Oxford University Press.

Frank, J. (2005). A Democracy of Distinction: Aristotle and the Work of Politics. Chicago: University of Chicago Press.

Johannes Saresberiensis (1855). Polycraticus, sive de nugis curialium et vestigiis philosophorum. In: Johannes Saresberiensis, Opera Omnia. Tomus Unicus. Patrologia Latina, ed. J.-P. Migne, tomus 199, Paris.

John of Salisbury (1990). Policraticus. Of the Frivolities of Courtiers and the Footprints of Philosophers, ed. and trans. by C.J. Nederman. Cambridge: Cambridge University Press. 
Jordović, I. (2011). Aristotle on extreme tyranny and extreme democracy. Historia: Zeitschrift für Alte Geschichte, Bd. 60, H. 1, 36-64.

Kerner, M. (1977). Johannes von Salisbury und die Logische Struktur seines Policraticu. Wiesbaden: Franz Steiner Verlag.

Keyt, D. (2017). Aristotle's Political Philosophy. In: D. Keyt, Nature and Justice: Studies in the Ethical and Political Philosophy of Plato and Aristotle. Leuven: Peeters, 165-195.

Laarhoven van, J. (1984), "Thou shalt Not slay a tyrant!". The So-Called Theory of John of Salisbury. In: The World of John of Salisbury, ed. by M. Wilks. Oxford: Oxford University Press, 319-341.

Lorenz, H. (2006). The Brute Within: Appetitive Desire in Plato and Aristotle. Oxford: Clarendon.

Meier, Ch. (1990). The Greek Dyscovery of Politics, trans. by D. McLintock. Boston: Harvard University Press.

Nederman, C.J. (2005). John of Salisbury. Tempe, Arizona.

Nederman, C.J. (2015). John of Salisbury's Political Theory. In: Ch. Grellard \& F. Lachaud, A Companion to John of Salisbury. Leiden-Boston: Brill, pp. 258-288.

O'Daly, I. (2018). John of Salisbury and the Medieval Roman Renaissence. Manchester: Manchester University Press.

Platon (1997). Politeia, ed. by O. Höffe. Berlin: Akademie Verlag.

Sasster, Y. (2015). John of Salisbury and Law. In: A Companion to John of Salisbury, ed. by Ch. Grellard, F. Lachaud. Leiden-Boston: Brill, 235-257.

Strauss, L. (2000). On Tyranny. Revised and expanded edition including the Strauss-Kojeve correspondence, ed. by V. Gourevitch, M.S. Roth, Chicago-London: The University of Chicago Press.

\section{Copyright and License}

This article is published under the terms of the Creative Commons Attribution - NoDerivs (CC BY- ND 4.0) License http://creativecommons.org/licenses/by-nd/4.0/ 